\title{
27. DATA REPORT: DETAILED LITHOSTRATIGRAPHY OF HOLE 893A, SANTA BARBARA BASIN, SOUTHERN CALIFORNIA CONTINENTAL BORDERLAND ${ }^{1}$
}

\author{
Richard J. Behl ${ }^{2}$
}

\section{INTRODUCTION}

The laminated (varved) sediments of Santa Barbara Basin have been intensively studied for their essentially undisturbed, high-resolution micropaleontologic and geochemical record of climatic and oceanographic change over the past several thousand years (Soutar and Isaacs, 1969; Soutar and Crill, 1977; Pisias 1978, 1979; Heusser, 1978; Dunbar, 1983; Lange et al., 1987, 1990; Schimmelmann and Tegner, 1991; Baumgartner et al., 1992). The principal purpose of Ocean Drilling Program (ODP) Site 893 was to extend this detailed record beyond the Holocene through the last glacial-interglacial cycles of the Quaternary ( 160 ka) (Kennett, Baldauf, et al., 1994). This volume contains numerous paleoceanographic and paleoclimatic studies that have accomplished that objective (e.g., Kennett and Venz; Kennett and Ingram; Hemphill-Haley et al.; Heusser). It is clear, however, that meaningful interpretation of paleoceanographic proxies (e.g., foraminiferal, diatom, or pollen assemblages, stable isotopes, or chemical composition) requires detailed knowledge of the sedimentologic context of individual samples. As Site 893 was a unique "site of opportunity," only $24 \mathrm{hr}$ were allocated at the end of Leg 146 (Cascadia Margin) to take advanced piston cores from the central Santa Barbara Basin, recovering $196.5 \mathrm{~m}$ at Hole 893A and $68.8 \mathrm{~m}$ at Hole $893 \mathrm{~B}$. Consequently, routine core description and physical property analyses were not completed aboard the JOIDES Resolution. Instead, the sectioned cores were shipped to the Gulf Coast Core Repository at College Station, Texas, where, 2 months later, they were split, photographed, and described by the shorebased scientific party (Kennett, Baldauf, et al., 1994). Because of limited time and personnel, the lithostratigraphy of the cores was described only to the $\sim 20$-cm resolution that is portrayed in the "barrel sheet" format of the Initial Reports, even though the core exhibits nearly continuous variation on the scale of centimeters.

The broad outline of the lithostratigraphy was presented by Kennett, Baldauf, et al. (1994) in which the core was separated into six $\sim 10$ - to 100-m-thick subunits (IA-IF) based largely on whether laminations were prevalent, intermittently present, or largely absent from the interval (Fig. 1). Most details of finer scale variation in lithology were not recorded, although the high sedimentation rate of the Santa Barbara Basin sediments $(\sim 120 \mathrm{~cm} / \mathrm{k} . \mathrm{y}$.) and the minor to complete absence of bioturbation make variation in sediment fabric an extremely high-resolution record of environmental change. Herein, the sedimentary facies of the sequence recovered from Hole $893 \mathrm{~A}$ are measured and described in detail as a record of environmental change in the Santa Barbara Basin and to provide a useful stratigraphic framework for the interpretation of individual samples analyzed by other researchers. The sample spacing of these observations $(0.5 \mathrm{~cm})$,

'Kennett, J.P., Baldauf, J.G., and Lyle, M. (Eds.), 1995. Proc. ODP, Sci. Results, 146 (Pt. 2): College Station, TX (Ocean Drilling Program).

${ }^{2}$ Marine Science Institute and Department of Geological Sciences, University of California, Santa Barbara, CA 93106-6150, U.S.A. when placed into a chronostratigraphic framework (see Kennett and Ingram, this volume; Ingram and Kennett, this volume), are equivalent to $<5$-yr increments over the past 160,000 yr. See Behl (this volume) for a detailed discussion of these data and the sedimentology of Site 893 .

\section{METHODS}

Lithology and sedimentary features were identified and logged at $0.5-\mathrm{cm}$ resolution by a detailed visual examination of the $196.5 \mathrm{~m}$ of core recovered from Hole $893 \mathrm{~A}$. The face of the archive half of the split core was prepared for examination and photography by careful scraping with a flat, negatively-charged metal blade to reveal numerous subtle or obscured details of sedimentary structure (Kennett, Baldauf, et al., 1994). In some cases, split cores that initially appeared to be massive proved to be pervasively laminated after this preparation.

The major sedimentary facies are described below and in Behl (this volume). Color of the damp sediment was determined by visual comparison with Munsell soil color charts (1971) under daylight-balanced light. Reverse and normal grading was identified visually by stratigraphic trends in texture or color (the two are distinguished in the Appendix, which appears on CD-ROM in the back pocket). Sediment texture (grain size) is classified as sand, silt, or mud (silt + clay) grain sizes according to Wentworth (1922) by use of a visual comparator card.

Bedding-parallel cracks due to gas expansion, ranging from $<1$ $\mathrm{mm}$ to several centimeters in thickness, are distributed unevenly throughout the core. The thickness of the gaps must be removed to determine the true stratigraphic thickness and position of different sedimentary facies. In the Appendix, all cracks or gaps greater than 3 $\mathrm{mm}$ in thickness are totaled and reported for each measured stratigraphic interval consisting of a single facies type. The total thickness of gaps in each interval is subtracted from the measured length of the interval to arrive at the true stratigraphic thickness of the interval. The amount of gas expansion voids identified in this report does not directly correspond to the gaps identified by digital color analysis (Kennett, Baldauf, et al., 1994; Merrill and Beck, this volume), as that study identified only stratigraphic gaps $>1 \mathrm{~cm}$ in thickness.

\section{RESULTS}

The Appendix (CD-ROM, back pocket) presents the lithostratigraphic data, referenced by core, section, and base of the described interval. The data include the total thickness of gas-expansion gaps in the interval, net (gap-corrected) thickness of interval, color, sedimentary facies (described below), indication of color or textural grading, texture (grain size), presence of burrows, description of bedding contacts, and miscellaneous comments. Color notation is annotated with "gry" for intervals in which the sediment is distinctly gray to the eye, rather than an olive-gray hue. Within the "Comments" column, "forams" indicates that $>2$ foraminiferal tests $/ \mathrm{cm}^{2}$ are visible on the 

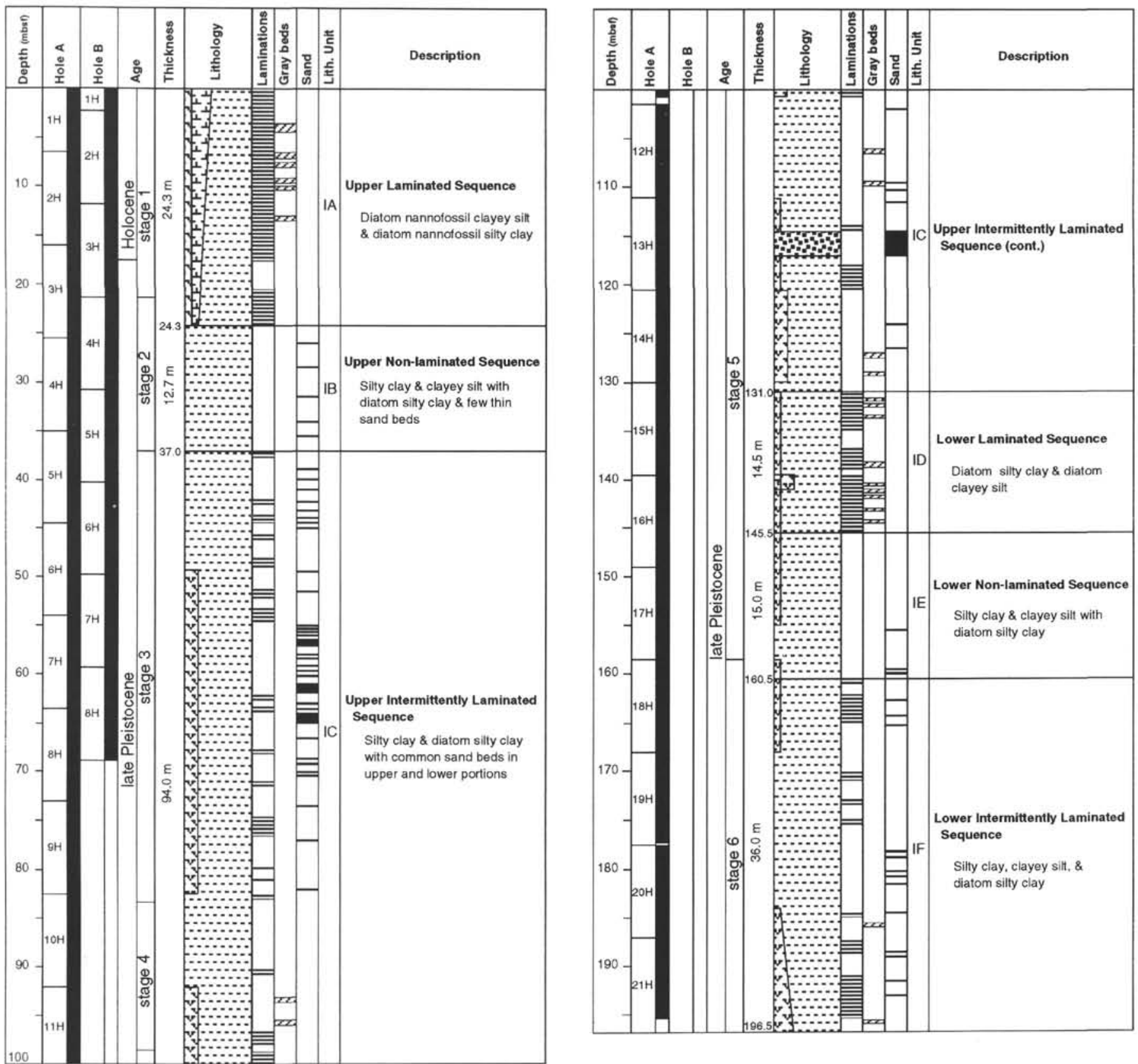

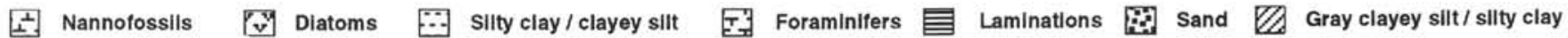

Figure 1. General lithostratigraphy of Holes $893 \mathrm{~A}$ and $893 \mathrm{~B}$ showing average compositions and locations of intervals bearing laminations, sand beds, and gray layers. Modified from Kennett, Baldauf, et al. (1994).

scraped cut surface of the half-round core and "abundant forams" indicates that $>5$ foraminiferal tests $/ \mathrm{cm}^{2}$ are visible. "Mica" indicates that mica flakes are abundant on the cut surface of the core.

Six sedimentary facies are identified at Hole 893A; these are intercalated at scales from subcentimeter laminations to more than 1$\mathrm{m}$-thick beds. Distinction of these facies is based on sedimentary structures and grain size, as defined below (Fig. 2). Details of their sedimentology and environmental significance are examined in Behl (this volume). Facies 1-4 serve as a bioturbation or oxygenation index, representing increasing degree of bioturbation (see Behl, this volume).
Facies 1: well-laminated olive-gray mud. Facies 1 is composed of unbioturbated, fine-grained sediment displaying distinct, continuous laminations across the central part of the core. Individual laminations are generally $<1.0$ to $2.0 \mathrm{~mm}$ thick and arranged as couplets of dark siliciclastic-rich (winter) and light diatom-rich (spring-summer) layers (Soutar and Crill, 1977; Thornton, 1984).

Facies 2: indistinctly laminated olive-gray mud. Facies 2 is identified by the presence of diffuse, discontinuous, or irregular laminations. Individual laminations are for the most part thicker than in facies 1 , and typically range from 1.5 to $4 \mathrm{~mm}$ thick. Distinct burrows are rare. 
Facies 1:

well laminated hemipelagic mud

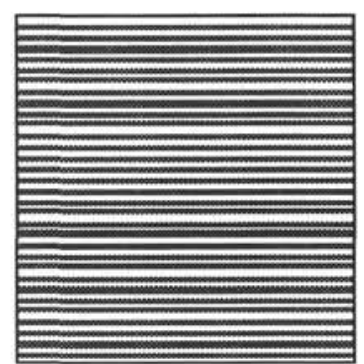

Facies 2:

indistinctly laminated hemipelagic mud

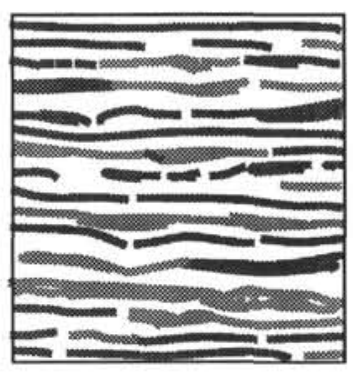

Facies 3 :

trace laminated hemipelagic mud

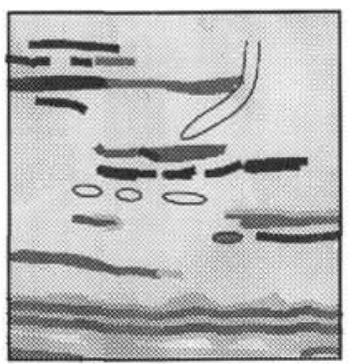

Facies 4:

massive hemipelagic mud

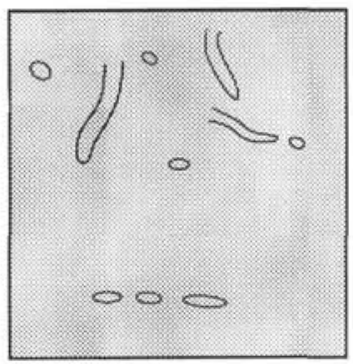

Facies 5: gray layer fine-grained event deposits

homogeneous suspensate/flood deposits graded clayey silt turbidites

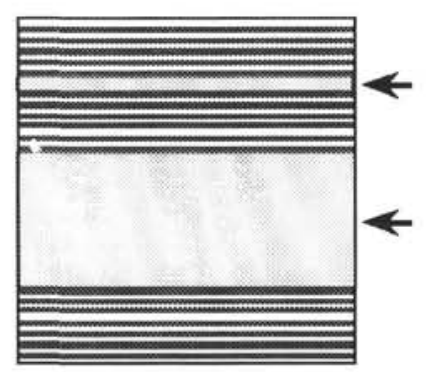

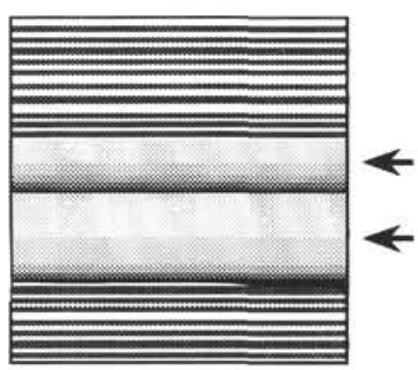

Facies 6:

sand turbidite

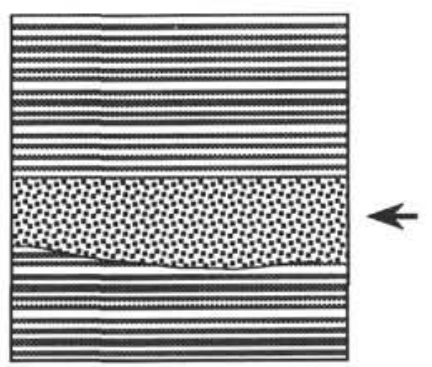

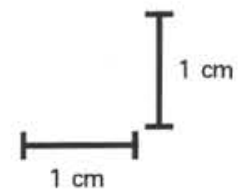

Figure 2. Representations of characteristic features of sedimentary facies in Hole 893A. Graphic scale is approximate.

Facies 3: olive-gray mud with traces of laminations. Facies 3 is identified by the presence of laterally limited patches of laminations separated by massive olive-gray mud. Alternately, facies 3 is assigned to an interval displaying extremely faint laminations with diffuse stratigraphic contacts.

Facies 4: massive olive-gray mud. Facies 4 is composed of olivegray mud containing no discernible primary fabric.

Facies 5: gray layers. Facies 5 is characterized by the distinct lack of olive coloration and a decidedly gray appearance (generally $5 \mathrm{Y} 5 /$ 1). Gray layers typically have sharp bases and commonly display sharp tops. Some are micaceous or silty, especially at their bases. Many are normally graded in texture or in color (dark to light) whereas others are massive. Some thicker layers consist of amalgamations of up to four individual graded deposits.

Facies 6: sand deposits. Facies 6 is composed of very fine to finegrained quartzose to quartzo-feldspathic sand (see Marsaglia et al., this volume). Most deposits are $<1 \mathrm{~cm}$ in thickness; however, one is $\sim 2.5 \mathrm{~m}$ thick. Thicker beds $(>10 \mathrm{~cm})$ are typically disrupted by the coring process whereas thinner, undeformed layers commonly display textural grading and sharp bases; these are interpreted as coarsegrained turbidites (Thornton, 1984; Kennett, Baldauf, et al., 1994; Behl, this volume; Marsaglia et al., this volume).

\section{ACKNOWLEDGMENTS}

This research was supported by a postdoctoral fellowship from the Marine Science Institute, University of California at Santa Barbara. JOI/USSAC provided funds for travel to College Station for the core description. The assistance of the staff of the Ocean Drilling Program Gulf Coast Repository was greatly appreciated.

\section{REFERENCES}

Baumgartner, T.R., Soutar, A., and Ferreira-Bartrina, V., 1992. Reconstruction of the history of the Pacific sardine and northern anchovy populations over the past two millennia from sediments of the Santa Barbara basin, California. Calif. Coop. Oceanic Fisheries Invest. Rep., 33:24 40.

Dunbar, R.B., 1983. Stable isotope record of upwelling and climate from Santa Barbara Basin, California. In Thiede, J., and Suess, E. (Eds.), Coastal Upwelling, Its Sediment Record, Part B. Sedimentary Records of Ancient Coastal Upwelling: New York (Plenum), 217-246.

Heusser, L., 1978. Pollen in Santa Barbara Basin, California: a 12,000 year record. Geol. Soc. Am. Bull., 89:673-678.

Kennett, J.P., Baldauf, J.G., et al., 1994. Proc. ODP, Init. Repts., 146 (Pt. 2): College Station, TX (Ocean Drilling Program).

Lange, C.B., Berger, W.H., Burke, S.K., Casey, R.E., Schimmelmann, A., Soutar, A., and Weinheimer, A.L., 1987. El Niño in Santa Barbara basin: diatom, radiolarian, and foraminiferan responses to the "1983 El Niño" event. Mar. Geol., 78:153-160.

Lange, C.B., Burke, S.K., and Berger, W.H., 1990. Biological production off southern California is linked to climatic change. Clim. Change, 16:319329.

Munsell Soil Color Charts, 1971. Baltimore (Munsell Color).

Pisias, N.G., 1978. Paleoceanography of the Santa Barbara Basin during the last 8000 years. Quat. Res., 10:366-384.

, 1979. Model for paleoceanographic reconstructions of the California Current during the last 8000 years. Quat. Res., 11:373-386.

Schimmelmann, A., and Tegner, M.J., 1991. Historical oceanographic events reflected in ${ }^{13} \mathrm{C} /{ }^{12} \mathrm{C}$ ratio of total organic carbon in Santa Barbara basin sediment. Global Biogeochem. Cycles, 5:173-188.

Soutar, A., and Crill, P.A., 1977. Sedimentation and climatic patterns in the Santa Barbara Basin during the 19th and 20th centuries. Geol. Soc. Am. Bull., 88:1161-1172. 
Soutar, A., and Isaacs, J.D., 1969. History of fish populations inferred from fish scales in anaerobic sediments off California. Calif. Coop. Oceanic Fisheries Invest. Rep., 13:63-70.

Thornton, S.E., 1984. Basin model for hemipelagic sedimentation in a tectonically active continental margin: Santa Barbara Basin, California continental borderland. In Stow, D.A.V., and Piper, D.J.W. (Eds.), Finegrained Sediments: Deep-water Processes and Facies. Geol. Soc. Spec. Publ. London, 15:377-394.
Wentworth, C.K., 1922. A scale of grade and class terms of clastic sediments. J. Geol., 30:377-392.

Date of initial receipt: 26 September 1994

Date of acceptance: 8 February 1995

Ms 146SR-309 
APPENDIX

Detailed Lithostratigraphic Log of Sediment Facies

\begin{tabular}{|c|c|c|c|c|c|c|c|c|}
\hline $\begin{array}{l}\text { Core, section, } \\
\text { interval base } \\
\quad(\mathrm{cm})\end{array}$ & Gap & $\begin{array}{l}\text { Thickness } \\
(\mathrm{cm})\end{array}$ & Color & Facies & Grading & Texture & Burrows Contacts & Comments \\
\hline \multicolumn{9}{|l|}{$1 \mathrm{H}-1,0$} \\
\hline $\mathrm{IH}-\mathrm{I}, \mathrm{I3}$ & & 13 & $5 Y 4 / 2$ & 4 & & Mud & & Soupy consistency \\
\hline $1 \mathrm{H}-1,20$ & & 7 & $5 Y 4 / 2$ & 1 & & Mud & & \\
\hline $1 \mathrm{H}-1,23.5$ & & 3.5 & $5 Y 4 / 2$ & 2 & & Mud & & \\
\hline $1 \mathrm{H}-1,29.5$ & & 6 & $5 Y 4 / 2$ & i & & Mud & & \\
\hline $\mathrm{IH}-1,33$ & & 3.5 & $5 Y 4 / 2$ & 2 & & Mud & & \\
\hline $1 \mathrm{H}-1,35$ & & 2 & $5 Y 4 / 2$ & 4 & & Mud & & \\
\hline $1 \mathrm{H}-1,36.5$ & & 1.5 & $5 Y 5 / 1$ gry & 5 & & Mud & & \\
\hline $1 \mathrm{H}-1.41$ & & 4.5 & $5 Y 4 / 2$ & 2 & & Mud & & \\
\hline $1 \mathrm{H}-1.55$ & & 14 & $5 Y 4 / 2$ & 4 & & Mud & & \\
\hline $1 \mathrm{H}-1,58$ & & 3 & $5 Y 4 / 2$ & 2 & & Mud & & \\
\hline IH-1. 63.5 & & 5.5 & $5 Y 4 / 2$ & 1 & & Mud & & \\
\hline $1 \mathrm{H}-1.65 .5$ & & 2 & $5 Y 5 / 1$ gry & 5 & $\mathrm{C}$ & Mud & & \\
\hline IH-I, 68 & & 2.5 & $5 Y 4 / 2$ & 1 & & Mud & & \\
\hline $1 \mathrm{H}-1.70$ & & 2 & $5 Y 4 / 2$ & 2 & & Mud & & \\
\hline $1 \mathrm{H}-1,86$ & & 16 & $5 Y 4 / 2$ & 4 & & Mud + forams & & \\
\hline $1 \mathrm{H}-1,95$ & & 9 & $5 Y 4 / 2$ & 3 & & Mud & & \\
\hline $1 \mathrm{H}-1,100$ & & 5 & $5 Y 4 / 2$ & 4 & & Mud & & \\
\hline $1 \mathrm{H}-1,102.5$ & & 2.5 & $5 Y 4 / 2$ & 1 & & Mud & & \\
\hline $1 \mathrm{H}-1,107$ & & 4.5 & $5 Y 4 / 2$ & 2 & & Mud & & \\
\hline $1 \mathrm{H}-1,115.5$ & & 8.5 & $5 \mathrm{Y} 4 / 2$ & 1 & & Mud & & \\
\hline $1 \mathrm{H}-1,120.5$ & & 5 & $5 Y 5 / 1$ gry & 5 & C & Mud & & 4 cycles, few laminations \\
\hline $\mathrm{IH}-1,122.5$ & & 2 & $5 Y 4 / 2$ & 2 & & Mud & & \\
\hline $1 \mathrm{H}-1,126$ & & 3.5 & $5 Y 4 / 2$ & 4 & & Mud & & \\
\hline $\mathrm{IH}-1,136$ & & 10 & $5 Y 4 / 2$ & 2 & & Mud & & \\
\hline $1 \mathrm{H}-1,136.5$ & & 0.5 & $5 Y 5 / 1$ gry & 5 & & Mud & & \\
\hline $1 \mathrm{H}-1,140$ & & 3.5 & $5 Y 4 / 2$ & 4 & & Mud & & \\
\hline $1 \mathrm{H}-1,148.5$ & & 8.5 & $5 Y 4 / 2$ & i & & Mud & & \\
\hline $\begin{array}{l}\mathrm{IH}-1,150 \\
\mathrm{IH}-2,0\end{array}$ & & 1.5 & \multicolumn{6}{|c|}{$1 \mathrm{H}-2,0$} \\
\hline $\mathrm{IH}-2, \mathrm{I}$ & & 1 & $5 Y 5 / 1$ gry & 5 & C & Mud & & \\
\hline $\mathrm{IH}-2,3.5$ & & 2.5 & $5 \mathrm{Y} 4 / 2$ & 2 & & Mud & & \\
\hline $\mathrm{IH}-2,7.5$ & & 4 & $5 Y 4 / 2$ & 1 & & Mud & & \\
\hline $\mid \mathrm{H}-2,11$ & & 3.5 & $5 Y 4 / 2$ & 2 & & Mud & & \\
\hline $1 \mathrm{H}-2,18$ & & 7 & $5 Y 4 / 2$ & 1 & & Mud & & \\
\hline $1 \mathrm{H}-2,25.5$ & & 7.5 & $5 Y 4 / 2$ & 4 & & Mud & & \\
\hline $1 \mathrm{H}-2,27.5$ & & 2 & $5 Y 4 / 2$ & 2 & & Mud & & \\
\hline $\mathrm{IH}-2,33.5$ & & 6 & $5 Y 4 / 2$ & $i$ & & Mud & & \\
\hline $1 \mathrm{H}-2,36$ & & 2.5 & $5 Y 4 / 2$ & 3 & & Mud & & \\
\hline $1 \mathrm{H}-2,41.5$ & & 5.5 & $5 Y 4 / 2$ & 1 & & Mud & & \\
\hline $1 \mathrm{H}-2,43$ & & 1.5 & $5 Y 4 / 2$ & 2 & & Mud & & \\
\hline $1 \mathrm{H}-2,47.5$ & & 4.5 & $5 Y 4 / 2$ & $i$ & & Mud & & \\
\hline $\mathrm{IH}-2,52$ & & 4.5 & $5 Y 4 / 2$ & 2 & & Mud & & \\
\hline $\mathrm{IH}-2,55$ & & 3 & $5 Y 4 / 2$ & 1 & & Mud & & \\
\hline $1 \mathrm{H}-2,58.5$ & & 3.5 & $5 Y 4 / 2$ & 2 & & Mud & & \\
\hline $1 \mathrm{H}-2,60$ & & 1.5 & $5 Y 4 / 2$ & 1 & & Mud & & \\
\hline $1 \mathrm{H}-2,61$ & & 1 & $5 Y 5 / 1$ gry & 5 & C & Mud & & \\
\hline $1 \mathrm{H}-2,63$ & & 2 & $5 Y 4 / 2$ & 4 & & Mud & & \\
\hline $1 \mathrm{H}-2,64.5$ & & 1.5 & $5 Y 4 / 2$ & i & & Mud & & \\
\hline IH-2, 67.5 & & 3 & $5 Y 4 / 2$ & 2 & & Mud & & \\
\hline $1 \mathrm{H}-2,79$ & & 11.5 & $5 Y 4 / 2$ & 4 & & Mud & & \\
\hline $\mathrm{IH}-2,82$ & & 3 & $5 Y 4 / 2$ & i & & Mud & & \\
\hline IH-2, 88 & & 6 & $5 Y 5 / 1$ gry & 5 & $\mathrm{CT}$ & Mud & & \\
\hline $1 \mathrm{H}-2,91.5$ & & 3.5 & $5 Y 4 / 2$ & 1 & & Mud & & \\
\hline $1 \mathrm{H}-2,98$ & & 6.5 & $5 Y 4 / 2$ & 2 & & Mud & & \\
\hline $1 \mathrm{H}-2,102.5$ & & 4.5 & $5 Y 4 / 2$ & 3 & & Mud & & \\
\hline IH-2, 108 & & 5.5 & $5 Y 4 / 2$ & 2 & & Mud & & \\
\hline $1 \mathrm{H}-2,109.5$ & & 1.5 & $5 Y 5 / 1$ gry & 5 & CT & Mud & & \\
\hline $1 \mathrm{H}-2,117$ & & 7.5 & $5 Y 4 / 2$ & 2 & & Mud & & \\
\hline $1 \mathrm{H}-2,121$ & & 4 & $5 Y 4 / 2$ & 1 & & Mud & & \\
\hline $\mathrm{IH}-2,123.5$ & & 2.5 & $5 Y 4 / 2$ & 2 & & Mud & & \\
\hline $\mathrm{IH}-2,126.5$ & & 3 & $5 Y 4 / 2$ & $i$ & & Mud & & \\
\hline $1 \mathrm{H}-2,127$ & & 0.5 & $5 Y 5 / 1$ gry & 5 & $\mathrm{C}$ & Mud & & \\
\hline $1 \mathrm{H}-2,130$ & & 3 & $5 Y 4 / 2$ & 3 & & Mud & & \\
\hline $1 \mathrm{H}-2,133$ & & 3 & $5 Y 4 / 2$ & 2 & & Mud & & \\
\hline $1 \mathrm{H}-2,138$ & & 5 & $5 Y 4 / 2$ & 3 & & Mud & & \\
\hline $\mathrm{IH}-2,151$ & & 13 & $5 Y 4 / 2$ & 4 & & Mud & & \\
\hline \multicolumn{9}{|l|}{$\mathrm{IH}-3,0$} \\
\hline $1 \mathrm{H}-3,7$ & & 7 & $5 Y 4 / 2$ & 2 & & Mud & & \\
\hline $1 \mathrm{H}-3,10$ & & 3 & $5 Y 4 / 2$ & 4 & & Mud & & \\
\hline $1 \mathrm{H}-3,12.5$ & & 2.5 & $5 Y 4 / 2$ & 3 & & Mud & & \\
\hline $\mathrm{IH}-3,16$ & & 3.5 & $5 Y 4 / 2$ & 2 & & Mud & & \\
\hline $\mathrm{IH}-3,20$ & & 4 & $5 Y 4 / 2$ & 3 & & Mud & & \\
\hline $1 \mathrm{H}-3,23.5$ & & 3.5 & $5 Y 4 / 2$ & 4 & & Mud & & \\
\hline $\mathrm{IH}-3,36$ & & 12.5 & $5 Y 5 / 1$ gry & 5 & CT & Mud & & 3 cycles \\
\hline $\mathrm{IH}-3,38$ & & 2 & $5 Y 4 / 2$ & 4 & & Mud & & \\
\hline IH- $3,44.5$ & & 6.5 & $5 Y 4 / 2$ & 3 & & Mud & & \\
\hline
\end{tabular}

Notes: Explanation of headings: "Gap" denotes cumulative gaps or cracks in interval. "Color" is Munsell color notation; colors marked "gry" are distinctly gray to the eye compared with olive-gray colors, "blk" denotes black. "Facies" are described as: $1=$ well laminated; $2=$ indistinctly laminated; $3=$ trace laminations; $4=$ massive; $5=$ gray layer; $6=$ sand. See text for more detailed descriptions. "Grading" denoted by: C = color grading, $\mathrm{T}=$ textural grading. In "Comments" column, "Forams" indicates $>2$ tests/cm². "Abundant forams" indicates $>5$ tests $/ \mathrm{cm}^{2}$ when viewed on the scraped surface of the core.

Only the first page of this Appendix is reproduced here. The entire Appendix appears on the CD-ROM (back pocket). 